\title{
PENGARUH PRAKTIK GOOD CORPORATE GOVERNANCE TERHADAP PRAKTIK MANAJEMEN LABA \\ (Studi pada Perusahaan Perbankan yang terdaftar di Bursa Efek Indonesia tahun 2013-2017)
}

\author{
Rahma Febrina ${ }^{1}$, Ulfi Maryati ${ }^{2}$, Ferdawati ${ }^{3}$ \\ ${ }^{1}$ Email: rahmafebrina0@gmail.com \\ 2Email : ulfimaryati@gmail.com \\ ${ }^{3}$ Email : ferdawati.pnp@gmail.com
}

Jurusan Akuntansi, Politeknik Negeri Padang

\begin{abstract}
Abstrak
Laporan keuangan menjadi media bagi perusahaan untuk menyampaikan informasi mengenai pertanggungjawaban pihak manajemen terhadap kebutuhan pihak eksternal. Manajemen laba merupakan suatu suatu proses pengambilan langkah yang disengaja dalam batas prinsip akuntansi yang umum baik didalam maupun diluar batas. Penelitian ini bertujuan untuk menganalisis pengaruh good corporate governance yang terdiri dari dewan komisaris independen, kepemilikan manajerial dan kepemilikan institusional terhadap manajemen laba dengan menggunakan modified jones models dengan proksi discretionary accruals. Sampel yang digunakan adalah perusahaan perbankan yang listing di bursa efek indonesia periode 2013-2017 diambil menggunakan purposive sampling dengan jumlah sampel 22 perusahaan dan dianalisis dengan regresi berganda. Hasil penelitian ini menyatakan bahwa secara parsial yaitu dewan komisaris independen berpengaruh terhadap manajemen laba dengan arah yang positif, sedangkan kepemilikan manajerial dan kepemilikan institusional tidak berpengaruh terhadap manajemen laba. Secara simultan dewan komisaris, dewan komisaris independen, kepemilikan manajerial dan kepemilikan institusional tidak berpengaruh signifikan terhadap manajemen laba.
\end{abstract}

Kata kunci: Corporate Corporate Governance, Perbankan, Manajemen Laba

Financial reports are a medium for companies to convey information about the accountability of management to the needs of external parties. Earnings management is a deliberate process of taking steps within the limits of general accounting principles both inside and outside the limits. This study aims to analyze the influence of good corporate governance consisting of independent board of directors, managerial ownership and institutional ownership on earnings management by using modified jones models with proxy discretionary accruals. The sample used was a banking company listing in the Indonesia Stock Exchange in the 2013-2017 period using purposive sampling with a sample of 22 companies and analyzed by multiple regression. The results of this study state that partially that the independent board of directors affects earnings management in a positive direction, while managerial ownership and institutional ownership do not affect earnings management. Simultaneously the board of commissioners, independent board of directors, managerial ownership and institutional ownership have no significant effect on earnings management.

Key Word: Good Corporate Governance, , Banking, Earnings Management 


\section{Pendahuluan}

Pada saat sekarang ini manajemen laba telah menjadi sebuah fenomena umum yang terjadi di sejumlah perusahaan. Perkembangan yang ada di dalam dunia bisnis menuntut perusahaan untuk menciptakan suatu keunggulan dalam usahanya. Sumber daya perusahaan juga digunakan perusahaan untuk memenangkan kompetisi persaingan dalam pasar secara efektif. Salah satu alat ukur yang digunakan dalam perusahaan untuk mengetahui kinerja perusahaan adalah melihat besarnya angka laba yang diperoleh oleh perusahaan setiap tahunnya. Karena semakin tinggi laba yang dihasilkan suatu perusahaan dari tahun ke tahun dapat diasumsikan perusahaan mampu mengelola sumber dayanya secara maksimal dalam memperoleh keuntungan semaksimal mungkin dengan melihat laporan keuangan yang diterbitkan oleh perusahaan. Manajemen laba ini timbul sebagai dampak konflik adanya keagenan yaitu adanya ketidakselarasan kepentingan antara pemilik dengan manajemen. Sebagai agen, manajer secara moral bertanggungjawab untuk mengoptimalkan keuntungan para pemilik perusahaan, dan memaksimalkan kesejahteraan mereka. Manajemen sebagai pengelola perusahaan memiliki informasi yang lebih banyak mengenai kondisi perusahaan daripada pemegang saham itu sendiri. Hal ini memungkinkan manajemen untuk melakukan praktik akuntansi dengan berorientasi pada angka laba yang akan mengakibatkan rendahnya kualitas laba yang dilaporkan sehingga menyebabkan kesalahan dalam pembuatan keputusan.

Ada beberapa kasus yang terjadi di Indonesia, seperti Laporan Keuangan Bank Bukopin Tersandung Kasus Kartu Kredit pada tahun 2017. Dengan melihat contoh kasus tersebut, sangat relevan bila ditarik suatu pertanyaan tentang pengaruh praktik good corporate governance terhadap praktik manajemen laba. Tujuan dari good corporate governance adalah untuk menciptakan nilai tambah bagi semua pihak yang berkepentingan (stakeholdernya itu sendiri). Dengan adanya tata kelola perusahaan yang baik dapat meningkatkan nilai investasi dan menghasilkan nilai ekonomi jangka panjang yang berkesinambungan bagi para pemegang saham maupun masyarakat secara keseluruhan. Good corporate governance yang baik kemungkinan akan mengurangi praktik manajemen laba yang dilakukan oleh manajer. Good corporate governance memiliki beberapa prinsip yang juga berpengaruh pada manajemen laba, yaitu adanya kewajaran, akuntabilitas, transparasi, responsibilitas, dan independensi. Prinsip-prinsip good corporate governance memiliki beberapa tujuan yaitu memberikan kemudahan informasi mengenai akses investasi di dalam negri maupun diluar negri, mendapatkan pendapatan yang lebih murah, memberikan sebuah keputusan terhadap kinerja ekonomi perusahaan dan dapat meningkatkan kepercayaan stakeholder terhadap perusahaan. Disini salah satu tujuan penting pendirian suatu perusahaan itu adalah untuk meningkatkan kesejahteraan pemilik perusahaan atau memaksimalkan kekayaan perusahaan melalui peningkatan nilai perusahaan.

Dari informasi diatas, penulis tertarik untuk melakukan penelitian mengenai Pengaruh praktik good corporate governance terhadap praktik manajemen laba yang terdaftar di Bursa Efek Indonesia tahun 2013-2017. GCG dalam penelitian ini akan dilihat melalui komponen mekanisme internal GCG yang terdiri dari Ukuran Dewan Komisaris,Dewan Komisaris Independen, Kepemilikan Institusional, dan Kepemilikan Manajerial. 


\section{Tinjauan Pustaka Dan Perumusan Hipotesis Tinjauan Pustaka \\ Teori Agensi (Agency Theory)}

Timbulnya manajemen laba dapat dijelaskan dalam teori agensi dimana ketika pemilik perusahaan tidak mampu lagi mengelola perusahaan sendiri, pemilik harus melakukan kontrak dengan eksekutif untuk menjalankan perusahaan. Sebagai agen, manajer perusahaan secara moral bertanggung jawab untuk mengoptimalkan keuntungan para pemilik (principal) dan sebagai imbalannya akan memperoleh kompensasi sesuai kontrak kerja. Dengan demikian terdapat dua kepentingan yang berbeda dalam perusahaan sehingga masing-masing pihak berusaha mencapai tingkat kemakmuran yang dikehendaki. Hubungan keagenan adalah suatu kontrak dimana satu atau beberapa orang (pemberi kerja atau principal) mempekerjakan orang lain (agen) untuk melaksanakan sebuah jasa untuk mengambil keputusan agen (Jensen dan Meckling,1976).

Permasalahan keagenan yang terjadi di dalam perusahaan dapat diatasi dengan diterapkannya Good Corporate Governance (GCG). Good corporate governance dalam hal ini berperan penting dimana pengelolaan perusahaan harus diawasi dan dikendalikan untuk memastikan bahwa pengelolaan perusahaan dilakukan dengan kepatuhan atas berbagai peraturan dan ketentuan yang berlaku. Bagi pemegang saham, good corporate governance memberikan jaminan bahwa dana yang diinvestasikan pada perusahaan dikelola dengan baik dan akan memberikan nilai yang memadai. Seorang pemegang saham pada dasarnya menghendaki bertambahnya kemakmuran atau kekayaan, namun manajer sebagai pihak yang diberi wewenang atas pengelolaan perusahaan cenderung melakukan sesuatu yang memaksimalkan kepentingannya dan mengorbankan kepentingan pemegang saham sehingga hal ini memicu terjadinya masalah keagenan. Permasalahan keagenan yang terjadi di dalam perusahaan dapat diatasi dengan diterapkannya Good Corporate Governance (GCG).

\section{Teori Stakeholder/Pemangku Kepentingan}

Stakeholder theory merupakan kinerja sebuah organisasi dipengaruhi oleh semua stakeholder organisasi, oleh karena itu merupakan tanggung jawab manajerial untuk memberikan benefit kepada semua stakeholder yang berpengaruh terhadap kinerja organisasi (Donaldson dan Preston,1995) dan (Muzzaki,2015). Perusahaan harus dapat memenuhi harapan para stakeholder dan memberikan nilai tambah kepada para stakeholder (Wahyudi,2015). Gray (1994) menyatakan bahwa dukungan stakeholder dapat mempengaruhi kelangsungan hidup perusahaan. Perusahaan harus mencari dukungan dengan melakukan aktivitas yang menunjukkan perhatian pada kepentingan stakeholder, sehingga pengungkapan tanggung jawab sosial dianggap sebagai cara yang ampuh untuk mendapat dukungan dari para stakeholder.

\section{Good Corporate Governance}

Menurut Sutedi(2006), Corporate governance merupakan Seperangkat peraturan yang mengatur hubungan antara pemegang saham, pengurus (pengelola) perusahaan, pihak kreditur, pemerintah, karyawan serta pemegang kepentingan intern dan ekstern lainnya yang berkaitan dengan hak dan kewajiban mereka. Menurut Forum for Corporate Governance in Indonesia (FCGI,2001) mendefinisikan Corporate Governance sebagai seperangkat peraturan yang mengatur hubungan antara pemegang saham, pengurus (pengelola) perusahaan, pihak kreditur, pemerintah karyawan serta para pemegang kepentingan internal dan eksternal lainnya yang berkaitan dengan hak dan kewajiban mereka mengatur dan mengendalikan perusahaan. 


\section{Manfaat dan Tujuan Good Corporate Governance}

Menurut Agoes (2009-106) manfaat penerapan good corporate governance adalah Memudahkan akses terhadap investasi domestic maupun asing,mendapatkan biaya modal (cost capital) yang lebih murah,memberikan keputusan yang lebih baik dalam meningkatkan kinerja ekonomi perusahaan,m eningkatkan kepercayaan dan keyakinan dari para pemangku kepentingan terhadap perusahaan, dan melindungi direksi dan komisaris dari tuntunan hukum. Sedangkan Menurut Indonesia Institute for Corporate Governance (IICG,2009:40) untuk meminimalkan agency cost, meminimalkan cost of capital, meningkatkan nilai saham perusahaan dan mengangkat citra perusahaan.

\section{Mekanisme Corporate Governance}

Pengelolaan perusahaan (good corporate governance) itu sendiri dapat diartikan secara luas pada literatur yang ada dan terbatas. Secara terbatas,istilah tersebut berkaitan dengan hubungan antara manajer, direktur, auditor dan pemegang saham, sedangkan secara luas istilah pengelolaan perusahaan dapat meliputi kombinasi hukum, peraturan, aturan pendaftaran dan praktik pribadi yang meningkatkan perusahaan menarik modal masuk, memiliki kinerja yang bagus, menghasilkan keuntungan, serta memenuhi harapan masyarakat secara umum dan sekaligus kewajiban hukum. Keberadaan organ tambahan tersebut memiliki tanggung jawab yang berkaitan dengan pelaksanaan good corporate governance, yaitu:

\section{Ukuran Dewan Komisaris}

Menurut Undang-Undang Perseroan Terbatas Nomor 40 Tahun 2007 ayat 6 menjelaskan dewan komisaris adalah sebagai berikut:"Dewan komisaris adalah organ yang bertugas melakukan pengawasan secara umum yang khusus sesuai anggaran dasar serta member nasihat kepada direksi.

\section{Dewan Komisaris Independen}

Menurut Komite Nasional Kebijakan Governance (2006) komisaris independen sebagai berikut:" Komisaris Independen adalah anggota komisaris yang tidak bergabung dengan manajemen, anggota dewan komisaris lainnya dan pemegang saham pengendali, serta bebas dari hubungan bisnis atau hubungan lainnya yang dapat mempengaruhi kemampuannya untuk bertindak semata-mata demi kepentingan perusahaan."

\section{Kepemilikan Manajerial}

Kepemilikan manajerial adalah situasi dimana manajer memiliki saham perusahaan dengan kata lain sekaligus sebagai pemegang saham (Tjeleni,2013). Kepemilikan manajerial merupakan persentase kepemilikan saham oleh pihak manjemen (direktur dan komisaris), (Wahidahwati,2002).

\section{Kepemilikan Institusional}

Kepemilikan Instutisional adalah "Kondisi dimana memiliki saham dalam suatu perusahaan. Institusi tersebut dapat berupa pemerintah, institusi swasta maupun asing(Widarjo,2010:25). Kepemilikan Institusional merupakan proporsi saham yang dimiliki institusional pada akhir tahun yang diukur dalam persentase saham yang dimiliki oleh investor institusional dalam suatu perusahaan (Masdupi,2005). Kepemilikan institusional merupakan persentase kepemilikan saham perushaan yang dimiliki investor institusional seperti pemerintah, perusahaan investasi, bank, perusahaan asuransi maupun kepemilikan lembaga dan perusahaan lain.

\section{Manajemen Laba}

Menurut Schipper (1989) dalam mendefinisikan manajemen laba sebagai suatu intervensi dengan maksud tertentu terhadap proses pelaporan keuangan eksternal dengan sengaja untuk memperoleh beberapa keuntungan pribadi. Fischer dan Rosenzweig (1995) dalam Padmantyo (2010) mendefinisikan manajemen laba sebagai tindakan seorang manajer 
dengan menyajikan laporan yang menaikan (menurunkan) laba periode berjalan dari unit usaha yang menjadi tanggungjawabnya.

\section{Perumusan Hipotesis}

\section{Pengaruh Praktik Good Corporate Governance terhadap Dewan Komisaris Independen}

Dewan komisaris independen yang merupakan bagian dari komisaris perseroan mempunyai pengawasan yang lebih baik terhadap manajemen. Dengan kata lain semakin besar jumlah dewan komisaris independen akan semakin besar pula tindakan manajemen laba, karena semakin berkurang efektif monitoring yang dapat dilakukan dewan komisaris terhadap manajemen dalam pengelolaan manajemen laba. Menurut Mahariana dan Agus (2016) dewan komisaris independen berpengaruh positif terhadap manajemen laba.

H1:Ukuran dewan komisaris independen berpengaruh positif terhadap manajaemen laba.

Pengaruh Praktik Good Corporate Governance terhadap Kepemilikan Manajerial

Kepemilikan manajerial adalah jumlah dari saham yang dimiliki oleh manajer perusahaan baik itu dewan direksi maupun komisaris dalam suatu perusahaan diluar saham yang dimiliki oleh para principal. Dimana saham yang dimiliki oleh manajer perusahaan relative kecil dari total seluruh saham yang ada dalam perusahaan tersebut. Dalam penelitian sebelumnya kepemilikan saham dalam tingkat manajerial dapat mengurangi praktik manajemen laba.

H2: Ukuran kepemilikan manajerial berpengaruh negatif terhadap manajemen laba. Pengaruh Praktik Good Corporate Governance terhadap Kepemilikan Institusional Kepemilikan institusional didefinisikan sebagai proporsi kepemilikan saham pada akhir tahun yang dimiliki oleh lembaga seperti asuransi, perbankan atau institusi lain. Kehadiran kepemilikan institusional ini memiliki peran yang sangat besar untuk melakukan pengawasan terhadap manajemen dan kebijakan perusahaan. Tindakan pengawasan tersebut dapat mendorong manajer untuk lebih fokus terhadap kinerja perusahaan, sehingga dapat mengurangi prilaku manajemen laba yang dilakukan oleh manajer. Peneliti menyatakan bahwa kepemilikan institusional yang tinggi dapat meminimalisir praktik manajemen laba ,namun tergantung pada jumlah kepemilikan yang cukup signifikan, sehingga dapat memonitor pihak manajemen yang berdampak mengurangi motivasi manajer untuk melakukan manajemen laba (Balsam et al.,2003).

H3 : Ukuran kepemilikan institusional berpengaruh negatif terhadap manajemen laba.

\section{Metode Penelitian \\ JENIS PENELITIAN}

Penelitian ini termasuk penelitian kuantitatif. Data yang digunakan dalam penelitian ini adalah data sekunder, yakni data yang diperoleh melalui perantara dari pihak kedua maupun media tertentu yang mendukung penelitian ini. Data penelitian ini bersumber dari laporan tahunan (annual report) perusahaan sektor perbankan yang listing di Bursa Efek Indonesia (BEI) selama periode 2013-2017 yang diperoleh dari situs resminya yaitu www.idx.co.id. Kemudian dilakukan analisis dengan menggunakan pendekatan discretionary accruals menurut The Modified Jones Model untuk memprediksi praktik manajemen laba pada perbankan konvensional di Indonesia.

\section{POPULASI DAN SAMPEL PENELITIAN}

Menurut V.Wiratna (2016:55) Populasi adalah keseluruhan jumlah yang terdiri atas objek atau subjek yang mempunyai karakteristik dan kualitas tertentu yang ditetapkan oleh peneliti untuk diteliti kemudian ditarik kesimpulannya. 


\section{Populasi Penelitian}

Populasi dalam penelitian ini adalah perusahaan perbankan konvensional 2013-2017 di Bursa Efek Indonesia (BEI) yang berjumlah 43 perusahaan sektor perbankan.

\section{Sampel Penelitian}

Pemilihan sampel dilakukan dengan menggunakan metode purposive sampling dengan tujuan untuk mendapatkan sampel yang representatif sesuai dengan kriteria yang ditentukan. Adapun kriteria dari sampel yang akan digunakan yaitu:

1. Perusahaan Perbankan yang terdaftar di BEI dan sahamnya aktif diperdagangkan selama periode 2013-2017.

2. Perusahaan yang menerbitkan laporan keuangan yang telah di audit untuk periode yang berakhir 31 Desember tahun 2013-2017.

Berdasarkan teknik pengambilan sampel diatas, maka sampel yang digunakan dalam penelitian ini sebanyak 22 perusahaan perbankan Indonesia yang listing di Bursa Efek Indonesia.

\section{DEFINISI OPERASIONAL DAN PENGUKURAN VARIABEL}

Dalam penelitian ini ada dua variabel yang digunakan yaitu variabel independen dan variabel dependen. Adapun penjelasan masing-masing variabel penelitian tersebut adalah sebagai berikut:

\section{Variabel Dependen}

Menurut Ambar (2010:55) variabel dependen adalah variabel yang dipengaruhi atau yang menjadi akibat karena adanya variabel independen.

\section{Earnings management}

Earnings management merupakan suatu intervensi dengan maksud tertentu terhadap proses pelaporan keuangan eksternal secara sengaja untuk memperoleh beberapa keuntungan pribadi (Schipper,1989 dalam Norbarani,2012). Earnings management muncul karena adanya kesempatan yang dimiliki oleh manajemen perusahaan untuk memilih kebijakan akuntansi yang digunakan dalam penyusunan laporan keuangan, salah satunya berbasis akuntansi akrual (Sihombing, 2014). Adapun pola analisis manajemen laba dengan pendekatan discretionary accruals menurut The Modified Jones Model adalah sebagai berikut :

$$
\mathrm{NDAt}=\alpha 1\left(1 / \mathrm{At}_{\mathrm{t}-1}\right)+\alpha_{2}\left(\left(\Delta R E V i_{t}-\Delta R E C i_{t}\right) / \mathrm{At}-1\right)+\alpha 3\left(P P E i_{t} / \mathrm{At}-1\right)
$$

\section{Variabel Independen}

Menurut Ambar (2010:55) variabel independen ini lebih dikenal dengan nama varibel bebas. Variabel bebas adalah variabel yang mempengaruhi suatu yang menjadi sebab perubahannya atau timbulnya variabel dependen/terikat.

\section{a. Dewan Komisaris Independen}

Komisaris independen adalah anggota dewan komisaris yang tidak terafiliasi dengan manajemen, anggota dewan komisaris lainnya dan pemegang saham pengendali, serta bebas dari hubungan bisnis atau hubungan lainnya yang dapat mempengaruhi kemampuannya untuk bertindak independen atau bertindak semata-mata demi kepentingan perusahaan (Komite Nasional Kebijakan Governance, 2004). Proporsi dewan komisaris independen diukur dengan menggunakan indikator persentase anggota dewan komisaris yang berasal dari luar perusahaan. 


$$
\mathrm{DKI}=\frac{\text { anggota dewan } \text { komisaris independen }}{\text { total dewan komisaris }}
$$

\section{b. Kepemilikan Manajerial}

Kepemilikan manajerial (manajerial ownership) adalah pemegang saham dari pihak manajemen yang secara aktif ikut dalam pengambilan keputusan. Kepemilikan manajerial merupakan persentase kepemilikan saham oleh pihak manajemen (direktor dan komisaris) (Wahidahwati, 2002).

\section{c. Kepemilikan Institusional}

$$
\text { MO }=\frac{\text { Jumlah lembar saham yang dimiliki manajemen }}{\text { total lembar saham yang beredar }} \times 100 \%
$$

Kepemilikan institusional (institusional ownership) merupakan presentase kepemilikan saham perusahaan yang dimiliki investor institusional seperti pemerintah, perusahaan investasi, bank, perusahaan asuransi maupun kepemilikan lembaga dan perusahaan lain. Kepemilikan institusional diukur dengan persentase kepemilikan institusi dalam struktur saham perusahaan (Juniarti et al, 2009).

$$
\text { IO }=\frac{\text { Jumlah lembar saham yang dimiliki institusi }}{\text { total lembar saham yang beredar }} \times 100 \%
$$

\section{Metode Analisis Data}

Teknik analisis data yang digunakan dalam penelitian ini adalah uji regresi linear berganda. Teknik analisis yang digunakan untuk menguji hipotesis yang telah dirumuskan dilakukan dengan bantuan program komputer IBM SPSS for Windows versi 20. Berikut metode analisis data yang digunakan dalam penelitian ini:

\section{Statistik Deskriptif}

Statistik deskriptif dalam penelitian pada dasarnya merupakan proses transformasi data penelitian dalam bentuk tabulasi sehingga mudah dipahami. Tabulasi menyajikan ringkasa, pengaturan atau penyusunan data dalam bentuk nilai maksimal,nilai minimal,nilai ratarata,nilai standar deviasi ( V.Wiratna 2016:77 ).

\section{Uji Asumsi Klasik}

Sebelum melakukan uji regresi linear berganda, perlu dilakukan uji asumsi klasik terlebih dahulu agar mendapatkan hasil yang terbaik. Tujuannya adalah dimaksudkan agar variabel bebas sebagai estimator atas variabel terikat tidak bias.

\section{Uji Normalitas}

Menurut Ghozali (2013) uji normalitas bertujuan untuk menguji apakah dalam model regresi, variabel penganggu atau residual memiliki distribusi normal. Penelitian ini menggunakan pengujian data dengan analisis grafik Normal P-P Plot yaitu dengan melihat penyebaran data atau titik yang mengikuti garis normal. Dan juga dengan analisis statistik Kolmogorov-Smirnov. Uji ini digunakan untuk menghasilkan angka yang lebih detail apakah suatu persamaan regresi dikatan normal atau tidak. Jika nilai uji KolmogorovSmirnov $>0.05$ berarti data terdistribusi normal

\section{Uji Multikolonieritas}

Uji multikolinieritas bertujuan untuk menguji apakah di dalam model regresi ditemukan korelasi antar variabel bebas independen. Untuk mendeteksi ada atau tidaknya multikolinieritas di dalam model regresi dapat dilihat dari nilai tolerance (tolerance value) dan nilai Variance Inflation Factor (VIF). Kedua ukuran ini menunjukkan 
setiap variabel bebas manakah yang dijelaskan oleh variabel bebas lainnya. Nilai cut off yang umum digunakan adalah nilai tolerance 0,10 atau sama dengan VIF diatas 10. Apabila nilai tolerance $>0,10$ atau nilai VIF < dari 10 maka dapat dikatakan bahwa tidak terjadi multikolinieritas antar variabel dalam model regresi.

\section{Uji Autokorelasi}

Uji Autokorelasi bertujuan menguji apakah dalam suatu model regresi linear ada korelasi antara kesalahan pengganggu pada periode $t$ dengan kesalahan pada periode $t-1$ (sebelumnya). Jika terjadi korelasi maka dinamakan ada problem autokorelasi. Model regresi yang baik adalah regresi yang bebas dari autokorelasi. Uji autokorelasi dapat dilakukan dengan menggunakan uji Durbin-Watson (D-W) dengan dasar pengambilan keputusan apabila du $<\mathrm{dw}<4$-du maka dikatakan tidak terjadi autokorelasi.

\section{Uji Heteroskedastisitas}

Uji heterokedastisitas bertujuan untuk menguji apakah dalam model regresi terjadi ketidaksamaan varian dari residual satu pengamatan ke pengamatan lainnya. Model regresi yang baik adalah homoskedastisitas dan tidak heterokedastisitas. Cara yang digunakan untuk mendeteksi ada tidaknya gejala heterokedastisitas dalam penelitian ini adalah dengan melihat model regresi yang terdapat ketidaksamaan varian residual suatu pengamatan ke pengamatan lain (Ghozali,2013).

Untuk mendeteksi ada tidaknya heteroskedastisitas dalam model regresi bisa dilihat dengan cara melihat Grafik Plot antara nilai prediksi variabel terikat yaitu ZPRED dengan residualnya SRESID. Jika tidak ada pola yang jelas, serta titik-titik menyebar di atas dan di bawah angka 0 pada sumbu Y maka tidak terjadi Heteroskedastisitas (Ghozali, 2013).

\section{Analisis Regresi Linear Berganda}

Analisis ini digunakan untuk mengukur kekuatan dua variabel atau lebih dan juga menunjukan arah hubungan antara variabel dependen dengan variabel independen. Model persamaan regresi yang akan diuji dalam penelitian ini adalah sebagai berikut:

$$
\text { DAit }=a+B_{1} X_{1}+B_{2} X_{2}+B_{3} X_{3}+B_{4} X_{4}+e
$$

Keterangan:

$$
\begin{array}{ll}
\text { DA i t } & =\text { Discretionary accruals perubahan i pada tahun } \mathrm{t} \\
\boldsymbol{a} & =\text { Koefisien regresi konstanta } \\
B & =\text { Koefisien regresi masing-masing proksi } \\
\boldsymbol{e} & =\text { error } \\
\mathrm{X}_{1} & =\text { Dewan Komisaris Independen (DKI) } \\
\mathrm{X}_{2} & =\text { Kepemilikan Manajerial (KM) } \\
\mathrm{X}_{3} & =\text { Kepemilikan Institusional (KI) }
\end{array}
$$

\section{Uji Hipotesis}

\section{a. Koefisien Determinasi (R2)}

Koefisien determinasi (R2) pada intinya mengukur seberapa jauh kemampuan model dalam menjelaskan variasi variabel independen. Nilai koefisien determinasi adalah antara nol dan satu. Nilai R2 yang kecil, menunjukkan bahwa kemampuan variasi variabel independen dalam menjelaskan variabel dependen amat terbatas atau lemah. Sedangkan nilai R2 yang mendekati satu, berarti hampir semua variasi variabel independen mampu 
memberikan informasi yang dibutuhkan dan pengaruhnya akan semakin kuat (Ghozali, 2013).

\section{b. (Uji F)}

Uji statistik F pada dasarnya menunjukkan apakah semua variabel bebas atau independen yang dimasukkan dalam model mempunyai pengaruh secara bersama-sama terhadap variabel terikat atau dependen. Untuk menguji hipotesis ini digunakan statistik F dengan kriteria pengambilan keputusan sebagai berikut (Ghozali, 2013):

1. Jika nilai $\mathrm{F}<0,05$ maka $\mathrm{H}_{0}$ ditolak, artinya semua variabel independen secara serentak dan signifikan mempengaruhi variabel dependen

2. Jika nilai $\mathrm{F}>0,05$ maka $\mathrm{H}_{0}$ tidak ditolak, artinya semua variabel independen secara serentak dan signifikan tidak mempengaruhi variabel dependen.

\section{c. Uji Parsial (uji t)}

Uji statistik t pada dasarnya menunjukkan seberapa jauh pengaruh satu variabel bebas atau independen secara individual dalam menerangkan variasi variabel dependen (Ghozali, 2013). Uji t digunakan dalam menentukan pengaruh variabel bebas terhadap variabel terikat dalam persamaan regresi berganda. Uji t juga digunakan untuk menguji kebenaran koefisien regresi dan melihat apakah koefisien regresi yang diperoleh berpengaruh atau tidak. Pengaruh atau tidaknya variabel independen terhadap variabel dependen dilakukan dengan melihat probabilitas (nilai sig).

\section{Uji Asumsi Klasik}

\section{Uji Normalitas}

Hasil uji normalitas dapat dilihat dari tabel dibawah ini.

Tabel 1 Hasil Uji Normalitas

\begin{tabular}{|c|c|c|c|c|c|}
\hline \multicolumn{6}{|c|}{ One-Sample Kolmogorov-Smirnov Test } \\
\hline & & Dki & kep.manajerial & kep_institusional & manajemen_laba \\
\hline \multicolumn{2}{|l|}{$\mathrm{N}$} & 97 & 97 & 97 & 97 \\
\hline \multirow[b]{2}{*}{$\begin{array}{l}\text { Normal } \\
\text { Parameters }^{\mathrm{a}, \mathrm{b}}\end{array}$} & Mean & 0.5771 & 0.0404 & 0.727 & 0.0041 \\
\hline & $\begin{array}{l}\text { Std. } \\
\text { Deviation }\end{array}$ & 0.10499 & 0.1299 & 0.2201 & 0.05166 \\
\hline \multirow{3}{*}{$\begin{array}{l}\text { Most } \\
\text { Extreme } \\
\text { Differences }\end{array}$} & Absolute & 0.171 & 0.407 & 0.145 & 0.122 \\
\hline & Positive & 0.171 & 0.407 & 0.107 & 0.122 \\
\hline & Negative & -0.149 & -0.378 & -0.145 & -0.059 \\
\hline \multicolumn{2}{|c|}{ Kolmogorov-Smirnov Z } & 1.682 & 4.009 & 1.432 & 1.206 \\
\hline \multicolumn{2}{|c|}{ Asymp. Sig. (2-tailed) } & 0.007 & 0 & 0.033 & 0.109 \\
\hline \multicolumn{6}{|c|}{ a. Test distribution is Normal. } \\
\hline \multicolumn{6}{|c|}{ b. Calculated from data. } \\
\hline
\end{tabular}

Sumber: Output IBM SPSS Ver. 20

Dari uji normalitas dengan menggunakan analisis statistik Non-parametric test. Uji ini dilakukan untuk mendapatkan angka yang lebih detail apakah suatu persamaan dikatatan berdistribusi normal. Persamaan regresi dikatatan bebas dari uji normalitas apabila nilai signifikansi uji Kolmogorov lebih besar dari 0,05 (Ghozali, 2013). Pada tabel di atas dapat dilihat bahwa hasil kolmogorov-smirnov Z sebesar 1.206 dan signifikan pada 0,109 . Hal ini berarti data residual berdistribusi normal karena lebih besar dari 0,05.

\section{Uji Multikolonieritas}

Pengujian multikolonieritas dilakukan dengan melihat nilai Tolerance dan Variance Inflation Factor (VIF) yang terdapat pada masing-masing variabel. Variabel dikatakan lulus uji multikolonieritas apabila nilai tolerance kurang dari 0,10 yang berarti tidak ada 
korelasi diantara variabel independen dan nilai VIF tidak lebih dari 10 (Ghozali, 2013). Hasil uji multikolonieritas dapat dilihat pada tabel dibawah ini:

Tabel 2 Hasil Uji Multikolonieritas

\begin{tabular}{|c|c|c|c|c|c|c|c|c|}
\hline \multicolumn{9}{|c|}{ Coefficients $^{\mathbf{a}}$} \\
\hline \multirow{2}{*}{\multicolumn{2}{|c|}{ Model }} & \multicolumn{2}{|c|}{$\begin{array}{l}\text { Unstandardized } \\
\text { Coefficients }\end{array}$} & \multirow{2}{*}{$\begin{array}{c}\text { Standardized } \\
\text { Coefficients }\end{array}$} & \multirow[t]{2}{*}{$\mathrm{t}$} & \multirow[t]{2}{*}{ Sig. } & \multicolumn{2}{|c|}{$\begin{array}{l}\text { Collinearity } \\
\text { Statistics }\end{array}$} \\
\hline & & B & $\begin{array}{l}\text { Std. } \\
\text { Error }\end{array}$ & & & & Tolerance & VIF \\
\hline & (Constant) & -0.058 & 0.039 & & 1.495 & 0.138 & & \\
\hline & Dki & 0.120 & 0.051 & 0.243 & 2.348 & 0.021 & 0.944 & 1.059 \\
\hline & kep.manajerial & -0.018 & 0.047 & -0.046 & 0.395 & 0.694 & 0.730 & 1.37 \\
\hline 1 & kep_institusional & -0.008 & 0.028 & -0.035 & 0.297 & 0.767 & 0.718 & 1.393 \\
\hline
\end{tabular}

Sumber: Output IBM SPSS Ver. 20

Dari tabel di atas dapat dilihat nilai tolerance masing-masing variabel lebih dari 0,10 yang berarti tidak ada korelasi antar variabel independen. Hasil perhitungan nilai VIF juga menunjukkan hal yang sama tidak ada variabel yang memiliki nilai VIF lebih besar dari 10. Jadi dapat disimpulkan bahwa tidak ada multikolonieritas antara variabel independen dalam model regresi.

\section{Uji Autokorelasi}

Pada uji autokorelasi, penulis menggunakan Uji Durbin - Watson (DW test). Dalam uji ini, pengambilan keputusan apakah data lulus uji autokorelasi di dasarkan pada rumus dU < DW < 4-dU. Nilai DW yang didapat dari hasil perhitungan SPSS harus lebih besar dari pada nilai du yang ada pada tabel Durbin - Watson dan nilai DW harus lebih kecil daripada hasil 4-du. Apabila hasil yang didapat telah memenuhi kriteria rumus di atas maka dapat dinyatakan bahwa data bebas dari autokorelasi (Ghozali, 2013). Hasil uji autokorelasi dapat dilihat pada tabel di bawah ini:

Tabel 3 Hasil Uji Autokorelasi

\begin{tabular}{|l|r|r|r|r|r|}
\hline \multicolumn{7}{|c|}{ Model Summary } \\
\hline Model & $\mathrm{R}$ & $\begin{array}{c}\mathrm{R} \\
\text { Square }\end{array}$ & $\begin{array}{c}\text { Adjusted } \\
\text { R Square }\end{array}$ & $\begin{array}{c}\text { Std. Error } \\
\text { of the } \\
\text { Estimate }\end{array}$ & $\begin{array}{c}\text { Durbin- } \\
\text { Watson }\end{array}$ \\
\hline 1 & $.246^{\mathrm{a}}$ & 0.06 & 0.03 & 0.05087 & 2.402 \\
\hline \multicolumn{7}{|l|}{ a. Predictors: (Constant), kep_institusional, dki, kep.manajerial } \\
\hline \multicolumn{4}{|l}{ b. Dependent Variable: manajemen_laba } \\
\hline
\end{tabular}

Sumber: Output IBM SPSS Ver. 20

Berdasarkan hasil pengujin autokorelasi untuk manajemen laba dengan menggunakan uji Durbin-Watson (DW-Test) dengan jumlah variabel independen (k) sebanyak 3 variabel, dengan jumlah observasi $(\mathrm{n})=97$ dan dengan $\alpha=5 \%$ dengan nilai durbin-lower $(\mathrm{dl})=1.6063$ dan durbin upper $(\mathrm{du})=1.7335$ sehingga $(4-\mathrm{du})=4-1.7335=$ 2.2665. dan ternyata nilai D-Watson sebesar 2.402 berada didaerah penerimaan H0 yaitu nilai DW > du $(2.403>1.7335)$. Hal ini berarti model yang diestimasi tidak terjadinya autokorelasi atau terbebas dari autokorelasi.

\section{Uji Heteroskedastisitas}


Tujuan melakukan uji heteroskedastisitas adalah untuk menguji apakah dalam model regresi terdapat ketidaksamaan varian residual suatu pengamatan ke pengamatan lain (Ghozali,2013). Terdeteksi ada tidaknya heteroskedastisitas dapat dilakukan dengan melihat ada atau tidaknya pola tertentu pada grafik scatterplot antara SRESID dan ZPRED dimana sumbu Y adalah Y yang di prediksi dan sumbu X adalah residual (Y prediksi-Y sesungguhnya) yang telah di studentized (Ghozali,2013). Berdasarkan pengujian dengan menggunakan SPSS diperoleh grafik Scatterplot sebagai berikut :

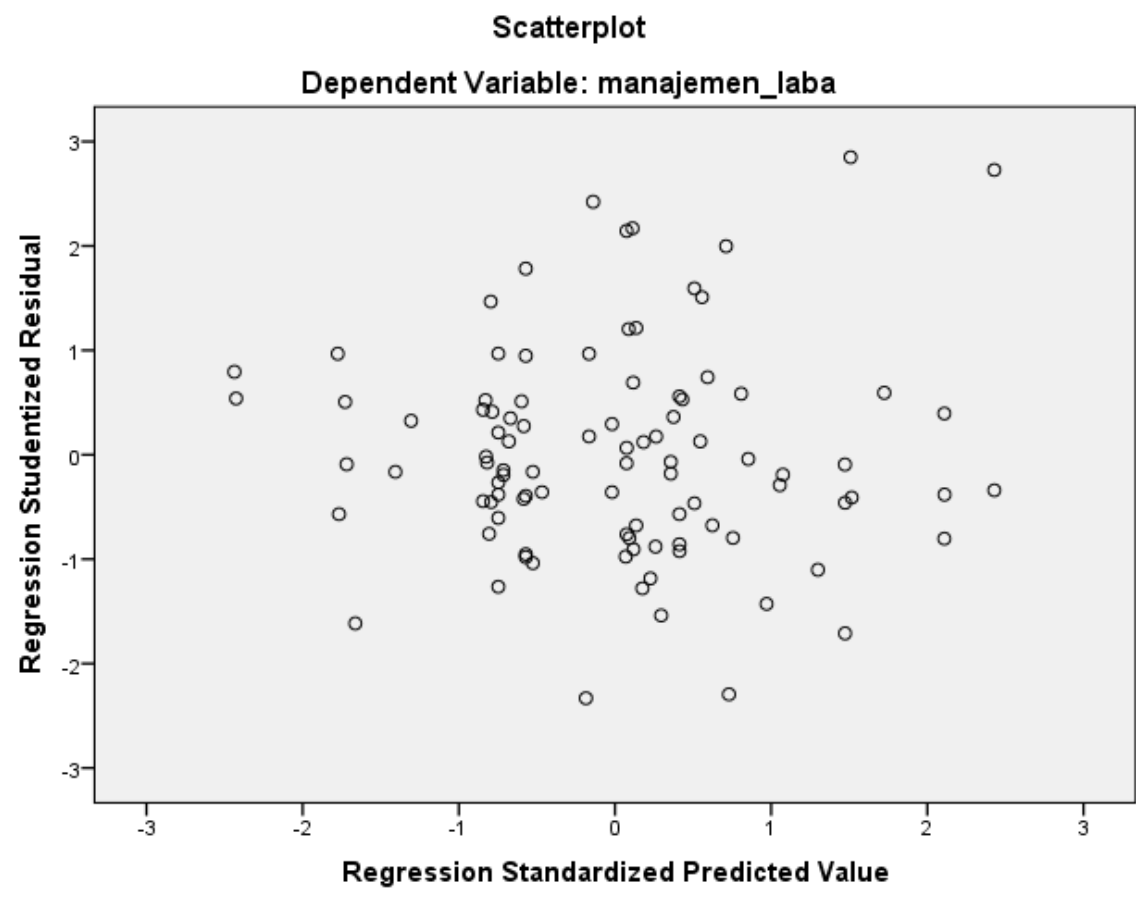

Sumber: Output IBM SPSS Ver. 20

\section{Gambar 1 Hasil Uji Heteroskedastisitas}

Dari grafik scatterplots di atas terlihat dapat disimpulkan bahwa titik-titik relatif tersebar secara acak dan tidak membentuk suatu pola yang jelas serta titik-titik tersebar diatas dan dibawah angka 0 pada sumbu Y. Dapat disimpulkan bahwa tidak terjadi gejala heteroskedastisitas pada persamaan regresi.

\section{Hasil Pengujian Regresi}

\section{Koefisien Determinasi (R2)}

Koefisien determinasi (R2) mengukur seberapa jauh kemampuan model dalam menerangkan variasi variabel dependen. Nilai Koefisien determinasi adalah antara nol dan satu (Ghozali, 2013). Hasil uji determinasi dapat dilihat pada tabel di bawah ini.

Tabel 4 Hasil Koefisien Determinasi

\begin{tabular}{|l|r|r|r|r|r|}
\hline \multicolumn{7}{|c|}{ Model Summary $^{\text {Model }}$} & R & R Square & $\begin{array}{c}\text { Adjusted R } \\
\text { Square }\end{array}$ & $\begin{array}{c}\text { Std. Error of the } \\
\text { Estimate }\end{array}$ & Durbin-Watson \\
\hline 1 & $.246^{\mathrm{a}}$ & .060 & .030 & .05087 & 2.402 \\
\hline a. Predictors: (Constant), kep_institusional, dki, kep.manajerial \\
\hline
\end{tabular}


b. Dependent Variable: manajemen_laba

Sumber: Output IBM SPSS Ver. 20

Berdasarkan tabel di atas dapat dilihat bahwa nilai Adjusted R2 adalah sebesar 0,030. Hal ini menunjukkan bahwa kemampuan variabel independen dalam menjelaskan atau memprediksi variabel dependen adalah sebesar 3\%, sedangkan sisanya sebesar 97\% dijelaskan oleh variabel lain diluar model regresi.

Uji Signifikansi Simultan (Uji F)

Uji statistik $\mathrm{F}$ pada dasarnya menunjukkan apakah semua variabel independen yang dimasukkan dalam model mempunyai pengaruh secara bersama-sama terhadap variabel dependen (Ghozali, 2013). Hasil uji F dapat dilihat pada tabel di bawah ini.

Tabel 5 Hasil Uji F

\begin{tabular}{|l|l|r|r|r|r|c|}
\hline \multicolumn{7}{|c|}{ ANOVA $^{\text {a }}$} \\
\hline \multirow{2}{*}{ Model } & $\begin{array}{c}\text { Sum of } \\
\text { Squares }\end{array}$ & \multicolumn{1}{c|}{ df } & $\begin{array}{c}\text { Mean } \\
\text { Square }\end{array}$ & F & Sig. \\
\hline \multirow{2}{*}{1} & Regression & .015 & 3 & .005 & 1.992 & $.121^{\text {b }}$ \\
\cline { 2 - 8 } & Residual & .241 & 93 & .003 & & \\
\cline { 2 - 8 } & Total & .256 & 96 & & & \\
\hline a. Dependent Variable: manajemen_laba \\
\hline b. Predictors: (Constant), kep_institusional, dki, kep.manajerial \\
\hline \multicolumn{7}{|l|}{ Sumber: Output IBM SPSS Ver. 20 } \\
\end{tabular}

Jadi dari hasil pengolahan data diatas menunjukkan bahwa nilai $\mathrm{F}=1.992$ dengan probabilitas ( $\mathrm{sig}$ ) sebesar $0.121>$ dari 0.05 . Berarti variabel bebas yang terdiri dari dewan komisaris independen, kepemilikan manajerial dan kepemilikan institusional secara bersama-sama tidak mempengaruhi variabel manajemen laba (Ghozali,2013). Hasil penelitian ini mendukung penelitian dari Isnanta (2008) bahwa good corporate governance tidak terbukti berpengaruh secara signifikan terhadap manajemen laba. Hal ini disebabkan karena penerapan good corporate governance merupakan hal yang baru di Indonesia, sehingga penerapannya belum dapat dilaksanakan secara optimal oleh masing-masing perusahaan. Tidak berpengaruhnya variabel independen terhadap manajemen laba kemungkinan disebabkan karena good corporate governance baru dirasakan dampaknya dalam waktu yang panjang, setelah semua aturan dilaksanakan sesuai mekanisme yang ada. Dan juga hasil penelitian ini mendukung hasil penelitian oleh Bunga Maharani,(2018) bahwa pengujian regresi menunjukkan nilai $\mathrm{F}$ sebesar 0.0551 dengan tingkat signifikannya sebesar 0.0699 dan nilai signifikansinya > 0.05 maka menunjukkan semua koefisien regresi variabel independen dalam penelitiannya bernilai 0 atau dengan kata lain tidak ada pengaruh variabel independennya terhadap manajemen laba.

\section{Hasil Uji Signifikansi (Uji Stastitik t)}

Uji t digunakan dalam menentukan pengaruh variabel bebas terhadap variabel terikat dalam persamaan regresi berganda. Uji $\mathrm{t}$ juga digunakan untuk menguji kebenaran koefisien regresi dan melihat apakah koefisien regresi yang diperoleh berpengaruh atau tidak. Pengaruh atau tidaknya variabel independen terhadap variabel dependen dilakukan dengan melihat probabilitas (nilai sig). Hasil pengujian dapat dilihat pada tabel dibawah ini 
Tabel 6 Hasil Uji Statistik t

\begin{tabular}{|c|c|c|c|c|c|c|}
\hline \multicolumn{7}{|c|}{ Coefficients $^{\mathrm{a}}$} \\
\hline \multirow{2}{*}{\multicolumn{2}{|c|}{ Model }} & \multicolumn{2}{|c|}{$\begin{array}{c}\text { Unstandardized } \\
\text { Coefficients } \\
\end{array}$} & \multirow{2}{*}{$\begin{array}{c}\begin{array}{c}\text { Standardized } \\
\text { Coefficients }\end{array} \\
\text { Beta }\end{array}$} & \multirow[t]{2}{*}{$\mathrm{T}$} & \multirow[t]{2}{*}{ Sig. } \\
\hline & & $\mathrm{B}$ & $\begin{array}{l}\text { Std. } \\
\text { Error }\end{array}$ & & & \\
\hline \multirow[b]{4}{*}{1} & (Constant) & -0.058 & 0.039 & & -1.495 & 0.138 \\
\hline & Dki & 0.120 & 0.051 & 0.243 & 2.348 & 0.021 \\
\hline & kep.manajerial & -0.018 & 0.047 & -0.046 & -0.395 & 0.694 \\
\hline & kep_institusional & -0.008 & 0.028 & -0.035 & -0.297 & 0.767 \\
\hline
\end{tabular}

Hipotesis pertama dalam penelitian ini adalah dewan komisaris independen berpengaruh positif terhadap manajemen laba. Berdasarkan hasil uji t di atas, dewan komisaris independen memiliki nilai signifikan sebesar 0,021 dan koefisien beta sebesar 0,120 . Nilai signifikansi yang berada di bawah 0,05 menunjukkan bahwa dewan komisaris independen memiliki pengaruh positif terhadap manajemen laba. Dengan demikian hipotesis 1 diterima.

Hipotesis keempat dalam penelitian ini adalah Kepemilikan Manajerial tidak berpengaruh terhadap manajemen laba. Berdasarkan hasil uji t di atas, Kepemilikan Manajerial memiliki nilai signifikan sebesar 0,694 dan koefisien beta sebesar -0,018. Dapat dilihat bahwa nilai signifikan variabel ini berada di atas 0,05 yang berarti secara statistik variabel ini tidak memiliki pengaruh terhadap manajemen laba. Dengan demikian hipotesis 2 ditolak.

Hipotesis ketiga dalam penelitian ini adalah Kepemilikan Institusional tidak berpengaruh terhadap manajemen laba dengan arah yang neagtif. Berdasarkan hasil uji t di atas, Kepemilikan Institusional memiliki nilai signifikan sebesar 0,767 dan koefisien beta sebesar 0,008. Dapat dilihat bahwa nilai signifikan variabel ini berada di atas 0,05 yang berarti secara statistik variabel ini tidak memiliki pengaruh terhadap manajemen laba. Dengan demikian hipotesis 3 ditolak.

\section{Pembahasan Hasil}

\section{Pengaruh Dewan Komisaris Independen terhadap Manajemen Laba}

Hasil penelitian menunjukkan bahwa dewan komisaris independen berpengaruh terhadap manajemen laba. Setelah dilakukan perhitungan dengan analisis regresi linear berganda dengan menggunakan program SPSS 2.0, koefisien regresi dewan komisaris independen menunjukkan nilai $\beta_{1}$ sebesar 0.120 dengan signifikan 0.021 lebih kecil dari tingkat signifikan 0.05. Hal ini menunjukkan bahwa dewan komisaris independen berpengaruh positif terhadap manajemen laba. Hasil penelitian ini sesuai dengan hasil penelitian yang dikemukakan oleh Ujiyanto dan Pramuka (2007) bahwa kehadiran dewan komisaris independen memiliki pengaruh signifikan positif terhadap manajemen laba perusahaan. Hal ini dapat dijelaskan bahwa pengangkatan dewan komisaris independen oleh perusahaan mungkin dilakukan untuk mengendalikan bisnis saja tapi tidak dimaksudkan untuk menegakkan Good Corporate Governance di dalam perusahaan (Sylvia dan Siddharta dalam Ujiyanto dan Setyawan,2007). 


\section{Pengaruh Kepemilikan Manajerial terhadap Manajemen Laba}

Hasil penelitian menunjukkan bahwa kepemilikan manajerial tidak berpengaruh terhadap manajemen laba. Setelah dilakukan perhitungan dengan analisis regresi linear berganda dengan menggunakan program SPSS 2.0, koefisien regresi kepemilikan manajerial menunjukkan nilai koefisien sebesar -0.018 dengan signifikan 0.694 lebih besar dari tingkat signifikan 0.05. Hal ini menunjukkan bahwa kepemilikan manajerial tidak berpengaruh terhadap manajemen laba . Penelitian ini mendukung hasil penelitian yang dilakukan oleh Midiastuty dan Machfoeds (2003) yang membuktikan bahwa kepemilikan manajerial tidak memiliki pengaruh terhadap manajemen laba. Hasil pengujian dari kepemilikan manajerial terhadap manajemen laba menunjukkan pengaruh yang tidak signifikan dengan arah negatif. Kepemilikan mnajerial tersebut akan mendorong manajemen perusahaan untuk meningkatkan dividen atas saham tiap tahunnya atas kepemilikan sebagian saham dari perusahaan tersebut. Sehingga semakin banyak saham yang dimiliki oleh manajemen maka praktik manajemen laba akan menurun karena jajaran manajemen akan berusaha untuk meningkatan laba perusahaan atas sahamnya dengan mealkukan kinerja yang baik, bukan dengan melakukan praktik manajemen laba. Dan ini mendukung penelitian dari Dian Agustia (2013) mengemukakan bahwa kepemilikan manajerial tidak berpengaruh terhadap manajemen laba dengan arah yang negatif karena kepemilikan manajerial perusahaan di Indonesia sangat kecil dengan rata-rata dibawah 5\%. Kegagalan pihak manajemen yang juga merupakan pemilik modal perusahaan dalam meningkatkan kualitas dan proses pelaporan keuangan disebebkan karena persentase manajer yang memiliki saham yang relatif kecil jika dibandingkan dengan keseluruhan modal yang dimiliki investor umum.

\section{Pengaruh Kepemilikan Institusional terhadap Manajemen Laba}

Dari hasil penelitian menunjukkan bahwa kepemilikan institusional tidak berpengaruh terhadap manajemen laba. Setelah dilakukan perhitungan dengan analisis regresi linear berganda dengan menggunakan program SPSS 2.0, koefisien regresi $\beta_{3}=-0.008$, kepemilikan institusional menunjukkan nilai t test (thitung) sebesar -0.767 dengan signifikan 0.469 lebih besar dari tingkat signifikan yaitu 0.05. Jadi dari setiap kenaikan 0,01 dari kepemilikan institusional akan menurunkan manajemen laba sebesar 0.008. Kepemilikan institusional tidak bisa membatasi terjadinya manajemen laba. Hal ini dikarenakan investor institusional tidak berperan sebagai investor yang memiliki lebih banyak kemampuan dan kesempatan untuk mendisiplinkan manajer agar lebih terfokus pada nilai perusahaan, serta membatasi kebijakan manajemen dalam melakukan manipulasi laba, melainkan berperan sebagai pemilik sementara yang lebih terfokus pada current earnings (Yang et al., 2009 dalam Agustia 2013). Penelitian ini juga mendukung hasil penelitian yang dilakukan oleh (Pranata dan Mas'ud,2003) mengungkapkan bahwa kepemilikan institusional adalah pemilik yang lebih memfokuskan pada current earning (laba tahun berjalan). Akibatnya pihak manajemen akan melakukan tindakan yang bisa meningkatkan laba jangka pendek, salah satunya dengan melakukan manipulasi laba. Oleh karena itu, adanya kepemilikan institusional belum tentu akan berdampak pada peningkatan proses pengawasan yang berpengaruh terhadap berkurangnya tindakan manajemen dalam melakukan manajemen laba. Hasil penelitian ini konsisten dengan penelitian Dian Agustia (2013) dan Deby Natalia (2013), yang hasilnya menunjukkan bahwa kepemilikan institusional tidak dapat mengurangi tindakan earnings management artinya tinggi rendahnya kepemilikan institusional tidak berdampak pada manajemen laba. 


\section{Kesimpulan, Keterbatasan Penelitian dan Saran \\ Kesimpulan}

Berdasarkan hasil analisis dan pembahasan yang telah dilakukan menggunakan metode analisis regresi linear berganda, diperoleh kesimpulan sebagai berikut:

1. Hasil pengujian menunjukkan bahwa variabel variabel good corporate governance yang diproksikan kedalam proporsi dewan komisaris independen (X1) berpengaruh positif signifikan terhadap manajemen laba perusahaan, karena pengangkatan dewan komisaris independen oleh perusahaan mungkin dilakukan untuk mengendalikan bisnis saja tapi tidak dimaksudkan untuk menegakkan Good Corporate Governance di dalam perusahaan.

2. Hasil pengujian menunjukkan bahwa variabel variabel good corporate governance yang diproksikan kedalam proporsi kepemilikan manajerial (X2) tidak berpengaruh terhadap manajemen laba, karena semakin banyak saham yang dimiliki oleh manajemen maka praktik manajemen laba akan menurun karena jajaran manajemen akan berusaha untuk meningkatan laba perusahaan atas sahamnya dengan mealkukan kinerja yang baik, bukan dengan melakukan praktik manajemen laba. Secara tidak langsung kepemilikan saham manajerial yang lebih besar bagi manajemen perusahaan dapat menurunkan kemungkinan praktik manajemen laba perusahaan.

3. Hasil pengujian menunjukkan bahwa variabel variabel good corporate governance yang diproksikan kedalam proporsi kepemilikan institusional (X3) tidak berpengaruh terhadap manajemen laba, karena kepemilikan institusional adalah pemilik yang lebih memfokuskan pada current earning (laba tahun berjalan). Akibatnya pihak manajemen akan melakukan tindakan yang bisa meningkatkan laba jangka pendek, salah satunya dengan melakukan manipulasi laba. Oleh karena itu, adanya kepemilikan institusional belum tentu akan berdampak pada peningkatan proses pengawasan yang berpengaruh terhadap berkurangnya tindakan manajemen dalam melakukan manajemen laba.

\section{Keterbatasan Penelitian}

Beberapa keterbatasan dalam penelitian ini adalah sebagai berikut:

1. Penelitian ini hanya dilakukan selama empat tahun pengamatan yaitu selama tahun 2013 sampai 2017. Penelitian selanjutnya diharapkan untuk menambah rentang waktu penelitian agar dapat memperoleh hasil yang lebih signifikan.

2. Adjusted R2 dalam penelitian ini baru 3\% yang menerangkan pengaruh good corporate governance terhadap manajemen dan sisanya masih terdapat $97 \%$ faktor lain yang mempengaruhi.

\section{Saran}

Disarankan kepada peneliti selanjutnya agar periode penelitian dapat dilakukan lebih dari lima tahun, sehingga dapat melihat kecenderungan perusahaan mempublikasikan laporan tahunan dalam jangka panjang. Penelitian ini hanya mengambil sampel perusahaan Perbankan sebagai sampel penelitian. Untuk penelitian selanjutnya akan lebih baik jika menambah jumlah sampelnya. Jumlah sampel yang lebih banyak akan memberikan hasil yang lebih valid. 


\section{Referensi}

A.A Intan Puspita Sari dan I G.A.M. Asri Dwija Putri. Pengaruh Mekanisme Corporate Governance pada Manajemen Laba.

Anastasia Endang Susilawati, Nanang Purwanto. 2015. Pengaruh Good Corporate Governance Pada Manajemen Laba. Journal Riset Mahasiswa Akuntansi.

Agustia, Dian. 2013. "Pengaruh Faktor Good Corporate Governance, Free Cash Flow dan Leverage Terhadap Manajemen Laba". Jurnal Akuntansi dan Keuangan Vol. 15, No. 1, Mei 2013, hlm. 27-42.

Ali,Masyhud.,2006, Manajemen Risiko, Strategi Perbankan Dan Dunia Usaha Menghadapi Tantangan Globalisasi Bisnis, PT. Raja Grafindo Persada, Jakarta.

Bambang, Sutopo 2009. Manajemen Laba dan Manfaat Kualitas Laba Dalam Keputusan Investasi. UNS, Tidak Dipublikasikan.

Bank Indonesia. 2006. Peraturan Bank Indonesia Nomor 8/14/PBI/2006 Perubahan Peraturan Bank Indonesia Nomor 8/4/PBI/2006 Tentang Pelaksanaan Good Corporate Governance Bagi Bank Umum.

Debby Natalia. 2013. Pengaruh Mekanisme Good Corporate Governance Terhadap Praktik Earning Management Badan Usaha Perbankan. Jurnal Ilmiah Mahasisiwa Universitas Surabaya, Vol.2, No.1.

Donaldson,T and Preston,L.E.1995.The Stakeholder Theory of the Corporation:Concept Evidence and Implication. The Academy of Management Review. 20(1):65-91

Effendi, Muh. Arief, 2009. "The Power of Good Corporate Governance Teori dan Implementasi”. Yogyakarta. Salemba Empat.

Faradila, Astri dan Cahyati Dewi Ari. 2013. Analisis Manajemen Laba Pada Perbankan Syariah. Jrak Vol. 4 No.1 Februari 2013 Hal. 57 - 74.

FGCI,2001. “Corporate Governance: Tata Kelola Perusahaan”. Edisi Ketiga, Jakarta.

Fathoni, Adi dan Hermawan Ancella A. 2013."Pengaruh Efektifitas Dewan Komisaris dan Komite Audit Terhadap Manajemen Laba untuk Perusahaan yang Terdaftar di BEI Tahun 2010 dan 2011".

Fischer, Marily; Kenneth Rosenzweig, 1995. Attitude of Students and Accounting Practitioners Concerning the Ethical Acceptability of Earnings Management. Journal of Business Ethics. Vol. 14. p. 433-444

Gibson, J.L. 2003. Struktur Organisasi dan Manajemen. Jakarta :Erlangga 5.

Ghozali, Imam. 2013. Aplikasi Analisis Multivariate Dengan Program IBM SPSS 20 Update PLS Regresi. Edisi ketujuh. Semarang: Badan Penerbit Universitas Diponegoro.

H.B. Sutopo (2006). Metodologi Penelitian Kualitatif : Dasar teori dan Terapannya dalam Penelitian Surakarta: Universitas Sebelas Maret. 
Iqbal, Syaiful dan Nurul Fachriyah, 2007, Corporate Governance Sebagai Alat Pereda Praktik Manajemen Laba,VenturaVol, 10, No, 3.

Jensen,Michael C. dan W.H. Meckling. 1976. Theory of The Firm : Managerial Behavior, Agency Cost and Ownership Structure. Journal of Financial Economics, Vol.3,h.305-360.

Jones, Jennifer J, 1991. Earnings Management During Import Relief Investigations. Journal Of Accounting Research, Vol 29, No.2 1991, p.193 - 228

Leo J. Susilo dan Karlen Simarmata, 2007. Good Corporate Governance pada Bank Tanggung jawab Direksi dan Komisaris dalam Menjalankannya,: Hikayat Dunia, Bandung.

Lestari, Eka dan Murtanto.2017. "Pengaruh Efektifitas Dewan Komisaris dan Komite Audit, Struktur Kepemilikan ,Kualitas Audit Terhadap Manajemen Laba. JMRA Vol. 17 No.2 September 2017: 97-116.

Masdupi, 2005." Analisis Dampak struktur kepemilikan pada Kebijakan Hutang dalam Mengontrol Konflik Keagenan.” Jurnal Ekonomi Bisnis vol.20, No.1. Desember $.56-69$.

Masodah. 2007.'Praktik Perataan Laba Sektor Industri Perbankan dan Lembaga Keuangan Lainnya dan Faktor yang Mempengaruhinya”. Proceeding PESAT (Psikologi, Ekonomi, Sastra, Arsitek dan sipil). Vol. 2,

Midiastuty, Pranata P.,dan Mas'ud Machfoedz. 2003. “Analisis Hubungan Mekanisme Good Corporate Governance dan Indikasi Manajemen Laba. Simposium Nasional Akuntansi VI, Surabaya, 16-17 Oktober, 2003, hal: 176-186.

Muliati, 2011, "Pengaruh Asimetri Informasi Dan Ukuran Perusahaan Pada Praktik Manajemen Laba Di Perusahaan Perbankan Yang Terdaftar Di BEI”, Universitas Udayana. Denpasar.

Nasution, Marihot dan Doddy Setiawan. 2007. Pengaruh Corporate Governance Terhadap Manajemen Laba di Industri Perbankan Indonesia. SNA X Makasar.

Praditia, Okta Rezika. 2010. Analisis Pengaruh Mekanisme Corporate Governance terhadap Manajemen Laba dan Nilai Perusahaan pada Perusahaan Manufaktur yang Terdaftar di Bursa Efek Indonesi (BEI) pada Tahun 2005-2008. Skripsi. Universitas Diponegoro, Semarang.

Rachmawati, Andri danTriatmoko, Hanung. 2007. "Analisis Faktor-Faktor yang Mempengaruhi Kualitas Laba dan Nilai Perusahaan”. Simposium Nasional Akuntansi X Makassar, 26-28 Juli.

Schipper, Katherine. (1989). Comentary Katherine on Earnings Management. Accounting Horizon.

Setiawati,Lilis dan Ainun Na'im.2000. Manajemen Laba. Jurnal Ekonomi dan Bisnis Indonesia, Vol.15,No 4,424-441. 
Sefiana, Eka. 2012. Penagruh Penerapan Corporate Governance Terhadap Manajemen Laba Pada Perusahaan Perbankan Yang Telah Go Public di BEI. Jurnal Akuntansi.

Sylvia Veronica N.P. Siregar dan Siddharta Utama, Pengaruh Struktur Kepemilikan, Ukuran Perusahaan, dan Praktek Corporate Governance Terhadap Pengelolaan Laba (Earnings Management). Simposium Nasional Akuntansi VIII, IAI, 2005.

Sochib, 2016. "Good Corporate Governance Manajemen Laba dan Kinerja Keuangan", Edisi 1. Yogyakarta: Depublish Agustus.

Sutedi, Adrian. (2011). Good Corporate Governance (Edisi 1). Jakarta: Sinar Grafika.

Sujarweni, V Wiratna. 2018. "Metodologi Penelitian Bisnis dan Efek Ekonomi Pendekatan Kuantitatif. ISBN:978-602-376-159-3.

Sulistyanto, H. Sri. 2008. "Manajemen Laba, Teori dan Model Empiris.Jakarta: Grasindo

Suryana, Agung. 2005. "Pengaruh Komite Audit Terhadap Kualitas Laba. Simposium Nasional Akuntansi VIII. 15-16 September 2005, Solo”.

Tarjo. 2008. "Pengaruh Konsentrasi Kepemilikan Institusional dan Leverage terhadap Manajemen Laba, Nilai Pemegang Saham serta Cost of Equity Capital.Simposium Nasional Akuntansi XI. Pontianak”.

The Indonesian Institute for Corporate Governance (IICG). 2009.Corporate Governance Perception Index 2008. (www.iicg.org). Diunduh 10 September 2013.

Tjeleni, Indra. "Pengaruh Kepemilikan Manajerial Dan Institusional Pengaruhnya Terhadap Kebijakan Hutang Pada Perusahaan Manufaktur Di Bursa Efek Indonesia. ISSN 2303-1174.

Ujiyanto, Moh. Arief dan Bambang Agus Pramuka, (2007), "Mekanisme Corporate Governance, Manajemen Laba dan Kinerja Keuangan (Studi Pada Perusahaan Go Publik Sektor Manufaktur), SNA X.

Wahidahwati. 2002. "Pengaruh Kepemilikan Manajerial Dan Kepemilikan Institusional Pada Kebijakan Hutang Perusahaan: Sebuah Perspektif Theory Agency ", Jurnal Riset Akuntansi Indonesia, Vol. 5, No.1, Januari: Hal 1-16.

Winanda, Arsita Putri. 2009. "Analisis Pengaruh Penerapan Good Corporate Governance dan Struktur Kepemilikan terhadap Kinerja Perusahaan." Skripsi. FE UNDIP

Widarjo, Wahyu.2010. Pengaruh Ownership Retention, Investasi Dari Proceeds, Dan Reputasi Auditor Terhadap Nilai Perusahaan Dengan Kepemilikan Manajerial Dan Institusional Sebagai Variabel Pemoderasi. Simposium Nasional Akuntansi XIII.

Winanda, Arsita Putri. 2009. “Analisis Pengaruh Penerapan Good Corporate Governance dan Struktur Kepemilikan terhadap Kinerja Perusahaan.” Skripsi. FE UNDIP 